\title{
PENGARUH KOMPETENSI GURU, MOTIVASI BERPRESTASI DAN BUDAYA ORGANISASI TERHADAP KINERJA MENGAJAR GURU MI MITRA PGMI UMI MAKASSAR
}

\author{
Dr. H. Akhmad Syahid, M.Pd. \& Dr. H. Syamsul Bachri, M.Ag.
}

\begin{abstract}
Abstrak
Kinerja seorang guru sangat dipengaruhi oleh banyak faktor diantaranya kompetensi dan motivasi . Kompetensi yang dimiliki oleh setiap guru tidaklah sama satu sama lain, pelatiah-pelatihan profesional keguruan yang pernah diikuti dan juga lamanya waktu pengalaman dalam mengajar juga cukup berepengaruh terhadap kompetensi seorang guru. Tidak kalah pentingnya dari kompetensi adalah motivasi, setiap orang pasti memiliki motivasi yang berbeda-beda, tidak terkecuali seorang guru juga memiliki motivasi untuk berprestasi. Kompensi guru dan motivasi tersebut dapat dilihat dari cara guru tersebut dalam mempersiapkan segala sesuatu untuk menunjang keberhasilan tujuan yang akan dicapai. Motivasi berprestasi adalah kondisi fisiologis dan psikologi yang terdapat dalam diri siswa yang mendorongnya untuk melakukan aktivitas tertentu guna mencapai tujuan tertentu. Bagian penting yang dapat mendukung adalah budaya organisasi dalam sebuah madrasah.
\end{abstract}

\section{A. Latar Belakang}

\section{PENDAHULUAN}

Kemajuan suatu bangsa sangat ditentukan oleh kualitas pendidikan. Oleh karena itu, pendidikan sebagai sarana untuk mencerdaskan kehidupan bangsa memiliki peranan yang sangat penting. Pendidikan ikut berperan di dalam mengembangkan sumber daya manusia yang bermutu, terampil, kreatif, inovatif, serta memiliki sikap dan prilaku yang positif.

Pendidikan merupakan suatu yang penting untuk kemajuan bangsa disamping ekonomi yang sehat, kebudayaan yang beraneka ragam, toleransi antar umat beragama. Hal itulah yang harus dipenuhi dalam upaya meningkatkan taraf hidup bangsa Indonesia agar tidak sampai tertinggal dengan bangsa lain. Pengembangan pendidikan dapat terbangun dari semangat dan motivasi belajar para generasi muda khususnya siswa-siswi yang duduk dibangku sekolah. Dikarenakan para siswa adalah pemegang tongkat estafet perjuangan bangsa yang sangat diharapkan kelak dapat membawa kebanggaan bagi bangsa Indonesia.

Seiring berjalannya waktu, pendidikan telah menjadi komoditas utama disetiap inti kehidupan manusia. Namun disisi lain, setelah diadakan sebuah observasi dibeberapa sekolah di Makassar, terkuak sebuah fakta dimana pendidikan mengalami sedikit kemunduran. Ada sebuah ketimpangan antara kompetensi guru, motivasi berprestasi dan budaya organisasi terhadap kinerja guru. 
Baik buruknya kinerja seorang guru sangat dipengaruhi oleh banyak faktor diantaranya kompetensi dan motivasi . Kompetensi yang dimiliki oleh setiap guru tidaklah sama satu sama lain, pelatiah-pelatihan profesional keguruan yang pernah diikuti dan juga lamanya waktu pengalaman dalam mengajar juga cukup berepengaruh terhadap kompetensi seorang guru. Tidak kalah pentingnya dari kompetensi adalah motivasi, setiap orang pasti memiliki motivasi yang berbedabeda, tidak terkecuali seorang guru juga memiliki motivasi dalam melakukan proses belajar mengajar.

Kompensi guru dan motivasi tersebut dapat dilihat dari cara guru tersebut dalam mempersiapkan segala sesuatu untuk menunjang keberhasilan tujuan yang akan dicapai. Motivasi berprestasi adalah kondisi fisiologis dan psikologi yang terdapat dalam diri siswa yang mendorongnya untuk melakukan aktivitas tertentu guna mencapai tujuan tertentu1. Sedangkan dilihat dari segi kompetensi, seorang guru mempunyai kesiapan dalam pembelajaran, meliputi penguasaan bahan ajar, kemampuan untuk menghubungkan materi kepada materi pokok yang akan disampaikan, strategi penyampaian materi pembelaran, tehnik penyampaian, kemampuan untuk membuat Rencana Pelaksanaan Pembelajaran agar sistematis dan dapat menggambarkan penyampaian materi pokok yang dinginkan silabus,serta kemampuan dalam pembuatan bahan evaluasi yang dapat mewakili setiap indikator dalam materi pokok.

Berdasarkan pengamatan awal yang telah dilakukan di sekolah Mitra PGMI UMI Makassar, diperoleh bahwa kompetensi guru masih belum produktif dalam mempersiapkan dan menyampaikan bahan ajar belum maksimal hal ini disebabkan karena masih kurangnya pengalaman dan minimnya pelatihan-pelatihan yang diikuti guru yang akan meningkatkan kompetensi guru. Guru produktif adalah guru yang dibekali kompetensi dalam bidang keguruan atau belajar mengajar yang sesuai standar profesi seorang guru. Maka diperlukan banyak penyesuaian bagi para guru agar menjadi guru yang baik dan profesional.

Begitupula dengan motivasi atau faktor pendorong sesorang menjadi guru akan menjadi penentu pula seseorang menjadi guru yang profesional, bagimana cara membuat perencanaan pemebelajaran, membuat RPP, melakukan proses pembelajaran dan sampai ke proses evaluasi yang baik perlu ditingkatkan dengan melakukan peltihan-pelatihan peningkatan kompetensi guru. Kompetensi yang belum optimal dapat mengakibatkan penurunan motivasi, begitupula dengan budaya organisasi sebagai faktor eksternal yang dapat berpengaruh pada motivasi dalam bekerja.

Berdasarkan uraian di atas, maka penulis akan melakukan penelitian yang berjudul “Pengaruh Kompetesi Guru, Motivasi Brprestasi dan Budaya Organisasi terhadap Kinerja Mengajar Guru MI Mitra UMI Makassar”.

\footnotetext{
${ }^{1}$ Djaali. Psikologi Pendidikan. Penerapan (Cet. III; Jakarta: Bumi Aksara: 2008), h. 103.
} 


\section{B. Rumusan Masalah dan Batasan Masalah}

1. Rumusan Masalah

Bertitik tolak dari latar belakang di atas maka dirumuskan permasalahan penelitian ini adalah:

a. Bagaimana kompetensi guru, motivasi berprestasi dan budaya organisasi terhadap kinerja guru Mitra PGMI UMI Makassar?

b. Berapa besar pengaruh Kompetensi sekolah terhadap kinerja guru Mitra PGMI UMI Makassar!

c. Berapa besar pengaruh motivasi berprestasi terhadapa kinerja guru Mitra PGMI UMI Makassar!

d. Berapa besar pengaruh budaya Organisasi terhadap kinerja guru Mitra PGMI UMI Makassar!

2. Batasan Masalah

Belum optimalnya kompetensi guru, motivasi berpertasi dan budaya organisasi sehingga berpengaruh pada kinerja guru Mitra PGMI UMI Makassar.

\section{Hipotesis}

Hipotesis adalah jawaban sementara dari rumusan masalah yang perlu membuktikan berdasarkan data yang telah dianalisis. ${ }^{2}$ Berdasarkan pada permasalahan dalam penelitian tindakan yang berjudul "Pengaruh Kompetensi Guru, Motivasi berprestasi dan Budaya Organisasi terhadap Kinerja Mengajar Guru MI Mitra UMI Makassar”, maka penulis mengemukakan hipotesis yaitu Berdasarkan kerangka pemikiran tersebut, maka hipotesis yang akan dirumuskan dalam penelitian ini adalah sebagai berikut :

1. Terdapat pengaruh dari kompetensi guru terhadap kinerja guru.

2. Terdapat pengaruh dari motivasi guru terhadap kinerja guru.

3. Terdapat pengaruh dari budaya organisasi sekolah terhadap kinerja guru.

4. Terdapat pengaruh dari budaya organisasi sekolah, kompetensi guru, dan motivasi guru secara simultan terhadap kinerja guru.

\section{Pengertian Judul dan Definisi Operasional}

\section{Pengertian Judul}

Untuk menghindari salah pengertian atau salah tafsir tentang makna istilah yang digunakan dalam penelitian ini, maka perlu dijelaskan pengertian judul sebagai berikut :

\footnotetext{
${ }^{2}$ Wina Sanjaya. Penelitian Pendidikan, (Cet. 1; Jakarta:Kencana, 2013), h. 12
} 
a. Pengaruh adalah ada atau timbul dari sesuatu (orang, benda) yang ikut membentuk watak, kepercayaan atau perbuatan sesorang. ${ }^{3}$

b. Kompetensi guru yaitu merupakan kemampuan seorang guru dalam melaksanakan kewajiban-kewajiban secara bertanggung jawab dan layak ${ }^{4}$.

c. Motivasi berprestasi adalah kondisi fisiologi dan psikologi (kebutuhan untuk berprestasi) yang terdapat dalam diri siswa yang mendorongnya untuk melakukan aktivitas tertentu guna mencapai suatu tujuan tertentu (berprestasi setinggi mungkin ${ }^{5}$

d. Budaya organisasi adalah nilai-nilai dan norma perilaku yang diterima dan dipahami secara bersama oleh anggota organisasi sebagai dasar dalam aturan perilaku yang terdapat dalam organisasi tersebut ${ }^{6}$.

e. Kenerja guru adalah bagaimana seorang guru merencanakan pembelajaran, melaksanakan kegiatan pemeblajaran dan penilaian hasil belajar ${ }^{7}$

2. Defenisi operasional

Adapun pengertian judul secara operasional adalah kemampuan seorang guru dalam motivasi untuk memberikanbelajar terhadap hasil belajar siswa agar termotivasi dengan baik dan hasil belajarnya semakin meningkat.

\section{E. Tujuan Dan Manfaat Penelitian}

1. Tujuan Penelitian Adapun tujuan penelitian ini adalah untuk mengetahui dan mengkaji :

a. Budaya organisasi sekolah, Kompetensi guru, motivasi guru, dan kinerja guru Mitra PGMI UMI Makassar

b. Besarnya pengaruh kompetensi guru terhadap kinerja Mitra PGMI UMI Makassar

c. Besarnya pengaruh Motivasi guru terhadap kinerja guru Mitra PGMI UMI Makassar

d. Besarnya pengaruh Budaya Organisasi Sekolah terhadap kinerja guru Mitra PGMI UMI Makassar

2. Manfaat Penelitian

Adapun dalam penelitian ini diharapakan dapt memberikan manfaat baik secara teoris maupun praktis bagi peneliti maupun bagi pihak sekolah.

a. Manfaat Teoritis.

\footnotetext{
${ }^{3}$ Mohamad Syarif Sumantri, Strategi Pembelajaran: Teori dan Praktik di Tingkat Pendidikan (Cet; Jakarta: Rajawali Pers; 2015), h. 15.

${ }^{4}$ Rusman .Belajar Dan Pembelajaran Berbasis Komputer, (Cet. 1; Bandung:Alfabeta, 2012), h. 37

${ }^{5}$ Djaali ., op.cit., h.124.

${ }^{6}$ http://www.artikelsiana.com/2015/10/pengertian-budaya-organisasi-fungsi.html di akses tgl 18 Oktober 2017

${ }^{7}$ Rusman ., op.cit., h.42.
} 
Hasil penelitian ini diharapakan dapat memberikan sumbangan pengetahuan bagi dunia pendidikan pada umunya dan dapat dijadikan acuan untuk penyusunan konsep pengembangan kinerja guru yang berhubungan dengan faktor-faktor yang diteliti di dalam penelitian ini yaitu yang berhubungan dengan Kompetensi Guru, dan Motivasi Guru dan Budaya Organisasai yang berpengaruh pada kinerja guru.

b. Manfaat Praktis.

Secara praktis penelitian ini diharapakan dapat memberikan manfaat bagi sekolah dan semua pihak yang ada di dalam lingkungan sekolah baik bagi diri saya sendiri maupun bagi semua guru di Mitra PGMI UMI Makssar untuk dapat mengevaluasi diri sekolah dan guru-guru sehingga dapat meningkatkan kompetensi guru, menciptakan iklim budaya organisasi yang nyaman dan kondusif dan saling memotivasi sesama guru sehingga tercapainya kinerja guru yang optimal meningkatnya mutu pendidikan di sekolah.

\section{KAJAN TEORI}

1. Pengertian kompetensi guru

Kompentensi merupakan perilaku rasiona luntuk mencapai tujuan yang dipersyaratkan sesuai dengan kondisi yang dipersyaratkan. Kompetensi guru merupakan kemampuan seorang guru dalam melaksanakan kewajiban-kewajibannya secara bertanggung jawab dan layak ${ }^{8}$. Pada hakikatnya tugas guru tidak hanya seharusnya diperlukan sebagai suatu tugas yang professional tetapi melihatnya sebagai suatu profesi utama, karena mengajar antara lain berarti turut meyiapkan subjek didik ke arah berbagai jenis profesi. Oleh karena itu guru merupakan tenaga yang turut menyiapkan tenaga pembangun lainnya.

Berdasarkan uraian di atas disimpulkan bahwa kompetensi guru sejatinya adalah mutlak dipenuhi karena merupakan kebulatan dari pengetahuan, keterampilan serta sikap yang ditampilkan dalam bentuk perilaku cerdas dan penuh tanggung jawab yang dimiliki oleh seorang guru dalam menjalankan profesinya.

2. Motivasi

Motivasi adalah suatu proses untuk mengigatkan motif-motif menjadi perubatan atau tingkah laku untuk memenuhi kebutuhan dan mencapai tujuan, atau keadaan dan kesiapan dalam diri individu yang mendorong tingkahlakunya untuk berbuat sesuatu dalam mencapai tujuan tertentu9. Dapat dikatakan bahwa motivasi itu sebagai sesuatu yang kompleks yang akan menyebabkan terjadinya suatu perubahan yang ada pada diri manusia, sehingga akan bertitik tolak dengan persoalan gejala kejiwaan, perasaan dan emosi untuk bertindak atau melakukan sesuatu.

\footnotetext{
${ }^{8}$ Rusman ., op.cit., h.42.

${ }^{9}$ HeriGunawan. Menjadi Guru Profesional(Cet II; Bandung: Rosdakarya,2005), h.
} 23. 
Motivasi merupakan faktor yang sangat penting dalam sebuah organisasi baik itu organisasi formal maupun non formal karena motivasi dapat mendorong setiap individu untuk bekerja dengan penuh semangat dan giat sesuai dengan peran, tugas dan tanggung jawabnya masing-masing guna mencapai tujuan organisasi yang telah ditetapkan. Di sekolah apabila setiap guru memiliki motivasi yang tinggi maka mereka akan bekerja sungguh-sungguh dan akan selalu meningkatkan kompetensinya guna mendukung tugas dan jabatan yang diembannya. Motivasi juga merupakan kecenderungan yang timbul pada diri seseorang secara sadar atau tidak sadar melakukan tindakan dengan tujuan tertentu ${ }^{10}$.

Berdasarkan penjelasan di atas dapat di tarik kesimpulan bahwa motivasi adalah usaha-usaha untuk menyediakan kegiatan-kegiatan untuk mencapai tujuan tertentu. Walaupun motivasi tumbuh di dalam individu, tetapi dalam perkembangannya dapat dirangsang oleh actor dari luar ${ }^{11}$.

3. Budaya Organisasi

Budaya Organisasi adalah suatu karakteristik yang dijunjung tinggi oleh organisasi dan menjadi pedoman organisasi sebagai pembeda antar organisassi. Pengertian budaya organisasi lain, budaya organisasi adalah nilai-nilai dan norma perilaku yang diteruima dan dipahami bersama oleh anggota organisasi sebagai dasar dalam aturan perilaku yang ada dalam organisasi ${ }^{12}$.

Budaya organisasi dalam penelitian ini menggunakan teori Deal and Kennedy bahwa unsur-unsur budaya organisasi meliputi :

1. Lingkungan usaha, yaitu lingkungan dimana perusahaan itu beroperasi dan akan menentukan apa yang harus dikerjakan oleh perusahaan tersebut untuk mencapai keberhasilan.

2. Nilai-nilai, merupakan konsep dasar dan keyakinan dari suatu organisasi.

3. Keteladanan/panutan, yaitu orang-orang yang menjadi panutan atau teladan karyawan lainnya karena keberhasilannya.

4. Upacara/Ritual, yaitu acara-acara yang diselenggarakan dalam rangka memberikan penghargaan pada karyawan.

5. Network, yaitu jaringan komunikasi informal di dalam organisasi yang dapat menjadi sarana penyebaran nilai-nilai dari budaya perusahaan. ${ }^{13}$

\section{Kinerja Guru}

Kinerja senantiasa berhubungan dengan prestasi yang dimiliki seseorang dalam menyelesaikan tugas-tugas individunya, kinerja juga merupakan persyaratan

\footnotetext{
${ }^{10}$ Tim Reality.KamusTerbaruBahasa Indonesia (Cet I; Surabaya: Reality Publisher,2008),h.456.

${ }^{11}$ HeriGunawan., op.cit., h.42.

${ }^{12} \mathrm{http}: / / \mathrm{www}$.pelajaran.co.id/2017/28/pengertian-budaya-organisasi-fungsi-ciri-tipecontoh-dan-teori-budaya-organisasi.html

${ }^{13}$ Laksmi Riani. Budaya Organisasi, (Cet II; Yogyakarta:Graha Ilmu,2011),h.11,12.
} 
yang harus dimiliki setiap individu dengan menyelesaikan tugas-tugasnya. Kinerja adalah suatu hasil kerja yang dicapai oleh seseorang dalam melaksanakan tugastugas yang dibebankan kepadanya berdasarkan atas kecakapan, pengalaman, kesungguhan, serta waktu"14.Kinerja setiap jabatan memiliki kriteria atau standar yang berbeda sesuai dengan deskripsi kerja masing-masing yang lebih spesifik. Setiap guru diharapkan dapat menyelesaikan tugas sesuai dengan standar yang telah ditetapkan.

Kinerja guru merupakan kemampuan seorang guru dalam melaksanakan tugas pembelajaran di madrasah dan bertanggungjawab atas peserta didik yang dibimbingnya dengan meningkatkan prestasi belajar peserta didik. Oleh karena itu, kinerja guru dapat diartikan sebagai suatu kondisi yang menunjukkan kemampuan seorang guru dalam menjalankan tugasnya di madrasah serta menggambarkan adanya suatu perbuatan yang ditampilkan guru dalam atau selama melakukan aktivitas pembelajaran. ${ }^{15}$ Kinerja guru dapat dilihat dari pelaksanaan tugasnya sehari-hari yaitu dalam melaksanakan kegiatan pembelajaran, pembimbingan, dan atau tugas tambahan yang relevan dengan fungsi sekolah.

Guru yang memiliki kinerja yang baik dan professional dalam implementasi kurikulum memiliki ciri-ciri, mendesain program pembelajaran, melaksanakan pembelajaran, dan menilai hasil belajar peserta didik. Perencanaan pembelajaran merupakan suatua ktivitas-aktivitas yang dilaksanakan sebelum pembelajaran itu sendiri dilaksanakan. Adapun kemampuan perencanaan pemebelajara nmeliputi tujuh hal, yaitu:

a. Memahami tujuan pemebelajaran, mengidentifikasi topic pembelajaran, dan menetapkan tujuan umum untuk setiap topic pembelajaran.

b. Mengenal karakteristik utama peserta didik.

c. Membuattujuanpemebelajaranmenjadispesifikdalambentuktingkahlakupesert adidiksehinggamemungkinkanuntukpengukuransecaralangsung.

d. Mengenali subjek da nisi setiap materi hingga pendukung bagi pencapaian tujuan.

e. Mengembangkanalatukurawalgunamenhetahui latar belakang peserta didik serta pengetahuannya mengenai topic yang akan diajarkan.

f. Menjaring kegiatan-kegiatan pembelajaran beserta sumber-sumbernya hingga peserta didik dapat mencapai tujuan.

g. Menggerakkan layanan-layanan yang mampu mendukung dan mengembangkan alat-alat evaluasi.

Adapun dimensi kinerja guru menurut Pedoman Penilaian Kinerja Guruadalah sebagai berikut :

1) Perencanaan pembelajaran

\footnotetext{
${ }^{14}$ Hasibuani.MenajemenSumberdayaManusia, (Cet II; Jakarta: Bumi Aksara,2008),h.94.

${ }^{15}$ Supardi.Kinerja Guru, (Cet I; Jakarta: RajawaliPers, 2013),h.54.
} 
Dimensi ini meliputi kemampuan guru dalam menyusun dan mengembangkan silabus serta RPP.

2) Pelaksanaan pembelajaran

Dimensi ini meliputi :

a. Pengelolaan kelas

b. Penggunaan media dan sumber belajar

c. Penggunaan metode pembelajaran

3) Pelaksanaan evaluasi/penilaian pembelajaran

Dimensi ini meliputi kemampuan guru dalam :

a. Menentukan pendekatan dan cara-cara evaluasi

b. Menyusun alat evaluasi

c. Mengolah hasil evaluasi

d. Menggunakan hasil evaluasi ${ }^{16}$

Ketiga dimensi tersebut di atas menjadi alat ukur dalam penilaian kinerja guru yang dilakukan secara periodik oleh sekolah terhadap semua guru dimana hasil dari penilaian ini dapat digunakan sebagai bahan pertimbangan dalam penyusunan program peningkatan dan pengembangan kompetensi guru selanjutnya.

\section{A. Jenis Penelitian}

\section{METODE PENELITIAN}

Berhasil tidaknya suatu penelitian tergantung kepada tepat guna tidaknya penerapan suatu metode yang dipilihnya. Jenis penelitian yang digunakan adalah penelitian Expostfacto. Penelitian dimana variabel-variabel independen (motivasi belajar) telah terjadi ketika peneliti mulai dengan pengamatan variabel dependen (hasil belajar) dalam suatu penelitian. Dalam penelitian ini, keterikatan antara variabel independen maupun variabel dependen sudah terjadi secara alami atau adanya hubungan sebab-akibat.

\section{B. Lokasi dan Waktu Penelitian}

Penelitian ini dilaksanakan di sekolah Mitra PGMI UMI Makassar. Alasan pemilihan lokasi tersebut karena adanya hubungan kemitraan Universitas Muslim Indonesia dengan beberapa sekolah MI di Makassar. Penelitian ini dilaksanakan dalam waktu kurang lebih 1 bulan dari tanggal 16 April - 16 Desember 2018.

\section{Desain Penelitian}

Sesuai dengan penjelasan maka secara umum dapat dijelaskan desain penelitian sebagai berikut:

${ }^{16}$ Wirawan.Peningkatan Mutu Pendidik dan Tenaga Kependidik(CetI;Jakarta:

DEPDIKNAS,2010) 


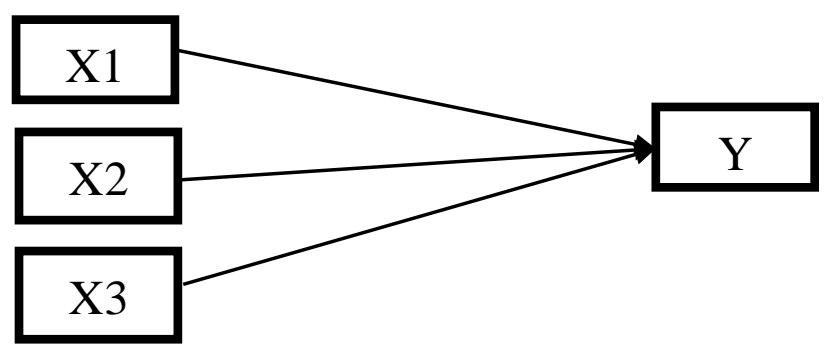

Gambar 3.1 Desain Penelitian

Di mana: $\quad \mathrm{X} 1:$ Kompetensi Profesional

$\mathrm{X} 2$ : Motivasi Berprestasi

$\mathrm{X} 3$ : Budaya Organisasi

Y : Kinerja mengajar

\section{Populasi dan Sampel Penelitian}

1. Populasi

Populasi adalah wilayah generalisasi yang terdiri atas objek/ subyek yang mempuanyai kualitas dan karakteristik tertentu yang telah ditetapkan oleh peneliti untuk dipelajari dan kemudian ditarik kesimpulannya ${ }^{17}$. Dalam sebuah penelitian untuk menjawab setiap permasalahan yang diteliti diperlukan data-data yang selanjutnya dianalisis untuk ditarik suatu simpulan. Data tersebut diperoleh dari suatu populasi yang menjadi obyek atau subyek penelitian. Berdasarkan uraian diatas maka yang menjadi populasi adalah seluruh guru Mitra PGMI UMI Makassar.

2. Sampel

Sampel adalah bagian dari jumlah dan karak teristik yang dimiliki oleh populasi tersebut ${ }^{18}$.

Berdasarkan jumlah populasi yaitu jumlah guru MI Mitra PGMI UMI jumlahnya hanya 59 orang, maka penelitian ini mengambil seluruh populasi sebagai sampel penelitian.

\section{E. Metode Pengumpulan Data}

Metode pengumpulan data yang akan digunakan antara lain:

1. Dokumentasi adalah ditujukan untuk memeperoleh data langsung dari tempat penelitian, meliputi buku-buku yang relevan, peraturan-peraturan, laporan kegiatan, foto-foto, dan data yang relevan penelitian ${ }^{19}$.

${ }^{17}$ Sugiono. Metode Penelitian Pendidikan Pendekatan Kuatitatif, Kualitatif, dan R \& D,(Cet. XV; Bandung: 2012). h. 117

${ }^{18}$ Ibid.h. 118 
2. Angket adalah sejumlah pertanyaan atau pernyataan tertulis yang digunakan untuk memperoleh informasi dari responden dalam arti laporan tentang pribadinya, atau hal-hal yang ia ketahui. ${ }^{20}$.Penulis menggunakan angket yang sifatnya tertutup, sehingga responden dalam hal ini guru hanya diberikan kesempatan untuk memilih alternative jawaban yang telah disediakan ${ }^{21}$. Angket yang diberikan berisi empat variabel yaitu: kinerja guru, kompetensi professional, budaya organisasi dan motivasi berprestasi. Sebaran butir-butir angket ditunjukkan pada tabel berikut ini:

\begin{tabular}{|l|c|}
\hline Variabel & Jumlah butir angket \\
\hline Kompetensi Profesional & 15 \\
\hline Motivasi berprestasi & 10 \\
\hline Budaya Organisasi & 10 \\
\hline Kinerja Mengajar & 10 \\
\hline Jumlah & 45 \\
\hline
\end{tabular}

\section{F. Validitas dan Reliabilitas}

Berikut ini pengertian validitas dan reliabilitas yaitu:

1. Validitas

"Validitas adalah suatu ukuran yang menunjukkan tingkat-tingkat kevalidan atau kesahihan sesuatu instrumen. Sebuah instrumen dikatakan valid apabila mampu mengukur apa yang diinginkan dengan kata lain dapat mengungkap data dari variabel yang diteliti secara tepat". ${ }^{22}$

Untuk mendukung analisis regresi dilakukan uji validitas dan uji realibilitas. Validitas menunjukkan sejauh mana ketepatan dan kecermatan suatu alat ukur dalam melakukan fungsi alat ukurnya.

Uji validitas berguna untuk mengetahui apakah ada pertanyaan-pertanyaan pada kuesioner yang harus dibuang / diganti karena dianggap tidak relevan. Dalam penelitian ini, uji validitas dilakukan secara statistik dengan dukungan komputer melalui bantuan paket software SPSS seri 22.

Dasar pengambilan keputusan yaitu sebagai berikut :

${ }^{19}$ Riduwan. Belajar Mudah Penelitian untuk Guru- Karyawan dan Peneliti Pemul,loc.cit. h.77

${ }^{20}$ Suharsimi Arikunto. Prosedur Penelitian Suatu Pendekatan Praktik, (Cet. XII; Jakarta: Rineka Cipta, 2006), h. 151

${ }^{21}$ Sugiono. Metode Penelitian Pendidikan Pendekatan Kuatitatif, Kualitatif, dan $R \&$ $D,($ Cet. XV; Bandung: 2012). h. 143

${ }^{22}$ Suharsimi Arikunt. Op Cit h. 211. 
a. Jika $\mathrm{r}$ hitung $>\mathrm{r}$ tabel (pada taraf signifikansi 5\%), maka pertanyaan tersebut dinyatakan valid

b. Jika $\mathrm{r}$ hitung < $\mathrm{r}$ tabel (pada taraf signifikansi 5\%), maka pertanyaan tersebut dinyatakan tidak valid

2. Reliabilitas

"Realiabilitas menunjuk pada satu pengertian bahwa sesuatu instrumen cukup dapat dipercaya untuk digunakan sebagai alat pengumpul data karena instrumen tersebut sudah baik". 23

Reliabilitas merupakan alat untuk mengukur suatu kuesioner yang merupakan indikator dari variabel. Uji reliabilitas dalam penelitian ini menggunakan program SPSS. SPSS memberikan fasilitas untuk mengukur reliabilitas dengan uji statistik Cronbach Alpha $(\alpha)$. Suatu konstruk atau variabel dikatakan reliabel jika memberikan nilai Cronbach Alpha $>0,60$

\section{a. Teknik Analisis Data}

Dalam penelitian ini, teknik analisis data yang diambil untuk mengetahui bagaimana pengaruh kompetensi guru, motivasi, budaya organisasi terhadap kinerja guru yaitu menggunakan metode analisis regresi linier. Hal ini berdasarkan karakteristik data dan juga model pengaruh yang diharapkan.

1. Mengolah setiap jawaban dari setiap angket yang telah disebarkan, memberi skor masing-masing pernyataan.

2. Memberikan skor terhadap jawaban responden dengan skala nilai:

a. Untuk jawaban Selalu diberi skor 4

b. Untuk jawaban Sering diberi skor 3

c. Untuk jawban Kadang-kadang diberi skor 2

d. Untuk jawaban Tidak Pernah diberi skor 1

Dari hasil responden tersebut akan dilakukan pengujian hipotesis dengan bantuan program SPSS versi 16. Adapun langkah-langkah hipotesis tersebut sebagai berikut:

3. Mencari presentasi frekuensi:

Dimana:

$$
P=\frac{f}{N} \times 100 \%
$$

$\mathrm{P}$ : Angka Presentase

$f$ : Frekuensi yang sedang dicari presentasenya

$\mathrm{N}$ : Jumlah frekuensi/banyaknya individu ${ }^{24}$

4. Uji Simultan (Uji F)

Sebelum melakukan uji korelasi maka terlebih dahulu melakukan uji simultan (uji F) variabel independen (motivasi belajar) terhadap variabel dependen

\footnotetext{
${ }^{23}$ Suharsimi Arikunto, op.cit., h. 221.

${ }^{24}$ Anas Sudijono, Pengantar Statistik Pendidikan (Cet.XXV; Jakarta : Rajawali Pers:2014), h. 43.
} 
(hasil belajar) untuk mengetahui uji $\mathrm{F}$ dapat digunakan skor signifikan yang ada pada hasil perhitungan olah data SPSS versi 16 sebagai berikut:

i. Merumuskan hipotesis statistik

1) Ho : $\beta_{1}=\beta_{2}=\beta_{3}=0$, artinya kompetensi professional, motivasi berprestasi dan budaya oraganisasi tidak berpengaruh signifikan terhadap kinerja guru.

2) Ha: $\beta_{1} \neq \beta_{2} \neq \beta_{3} \neq 0$, artinya kompetensi professional, motivasi berprestasi dan budaya oraganisasi berpengaruh signifikan terhadap kinerja guru.

ii. Kaidah pengambilan keputusan

Pengambilan keputusan dengan taraf signifikan $5 \%$ sebagai berikut:

1) Sig $<0,05 \longrightarrow$ Ho ditolak maka Ha diterima

2) Sig $>0,05 \longrightarrow$ Ho diterima maka Ha ditolak

5. Uji Pengaruh

Uji pengaruh yang dugnakan adalah menggunakan regresi linier dengan empat variabel. $^{25}$

Untuk membantu proses pengolahan data secara cepat dan tepat, maka pengolahan datanya melalui SPSS (Statistik Product and Service Solution) versi 16.

\subsection{Hasil Penelitian}

\section{HASIL DAN PEMBAHASAN}

\subsubsection{Karakteristik Responden}

Responden dalam penelitian ini adalah guru MI Mitra UMI Makassar yaitu MI Al-Hidayah, MI Ma'arif, MI Tajmilul Akhlaq, MI Al-Fitrah, dan MIN 2 Makassar sebanyak 59 responden yang penulis temui selama penelitian berlangsung.

Untuk memperjelas karakteristik responden yang dimaksud, maka disajikan tabel mengenai responden berikut ini:

Tabel 4.1

Guru MI Mitra UMI Responden

\begin{tabular}{|l|c|c|}
\hline \multicolumn{1}{|c|}{ MI Mitra } & Jumlah & Persentase \\
\hline MI Al-Hidayah & 12 & $20,3 \%$ \\
\hline MI Ma'arif & 8 & $13,6 \%$ \\
\hline MI Tajmilul Akhlaq & 8 & $13,6 \%$ \\
\hline MI Al-Fitrah & 5 & $8,5 \%$ \\
\hline MIN 2 Total & 26 & $44 \%$ \\
\hline \multicolumn{1}{|c|}{ Tor } & $\mathbf{5 9}$ & \\
\hline
\end{tabular}

Sumber: Data diolah, 2018

Berdasarkan tabel 4.1 di atas dapat diketahui bahwa guru MI Mitra UMI Makassar yaitu MI Al-Hidayah sebanyak 12 responden, MI Ma'arif sebanyak 8

\footnotetext{
${ }^{25}$ Ibid, h. 206.
} 
responden, MI Tajmilul Akhlaq sebanyak 8 responden, MI Al-Fitrah sebanyak 5 responden, dan MIN 2 sebanyak 26 responden jadi total sebanyak 59 responden.

\subsubsection{Analisis Hasil Deskriptif}

Analisis hasil deskriptif digunakan sebagai peringkasan data untuk mengetahui jawaban dari responden terhadap masing-masing pernyataan yang berada dalam instrumen penelitian. Adapun tanggapan responden dari masing-masing variabel adalah sebagai berikut:

1. Deskripsi Variabel Kompetensi Profesional Guru (X1)

\subsection{Hasil Pengujian Hipotesis}

\subsubsection{Analisis Regresi Linear Berganda}

Analisis regresi linear berganda digunakan untuk menguji hipotesis apakah ada pengaruh kompetensi guru (X1) motivasi berprestasi (X2) dan budaya organisasi (X3) terhadap kinerja mengajar guru (Y).

Analisis multivariat dilakukan untuk variabel yang berpengaruh terhadap kinerja guru. Dengan menggunakan uji regresi linear berganda bertujuan untuk mencari variabel yang paling dominan berpengaruh terhadap pengaruh kinerja guru.

Hasil analisis regresi adalah berupa koefisien untuk masing-masing variabel independent. Koefisien ini diperoleh dengan cara memprediksi nilai variabel dependent dengan suatu persamaan.

Tabel 4.5

Hasil Analisis Regresi Linear Berganda

\begin{tabular}{|c|c|c|c|c|c|}
\hline \multirow[t]{2}{*}{ Model } & \multicolumn{2}{|c|}{$\begin{array}{l}\text { Unstandardized } \\
\text { Coefficients }\end{array}$} & $\begin{array}{c}\text { Standardized } \\
\text { Coefficients }\end{array}$ & \multirow[t]{2}{*}{$\mathrm{t}$} & \multirow[t]{2}{*}{ Sig. } \\
\hline & B & Std. Error & Beta & & \\
\hline \multirow[b]{2}{*}{ Kompetensi Guru } & 20,405 & 4,081 & & 5,000 & 0,000 \\
\hline & 0,313 & 0,098 & 0,460 & 3,210 & 0,002 \\
\hline \multirow[t]{2}{*}{$\begin{array}{l}\text { Motivasi Berprestasi } \\
\text { Budaya Organisasi }\end{array}$} & 0,054 & 0,082 & $-0,090$ & 0,653 & 0,517 \\
\hline & 0,094 & 0,085 & 0,085 & 1,101 & 0,276 \\
\hline
\end{tabular}

Sumber: Data diolah, 2018 
Berdasarkan tabel 4.5 diatas dapat disimpulkan bahwa variabel kinerja guru dipengaruhi oleh beberapa variabel yang digunakan dalam penelitian, sehingga terbentuklah persamaan seperti berikut ini:

Y = 20,405 + 0,313 (Kompetensi Guru) + 0,054 (Motivasi Berprestasi) + 0,094 (Budaya Organisasi) + e

Berdasarkan hasil persamaan regresi dapat dijelaskan besarnya pengaruh masing-masing variabel independen terhadap variabel dependen adalah sebagai berikut:

a. Nilai konstanta diperoleh 20,405, artinya apabila kompetensi guru (X1), motivasi berprestasi (X2) dan budaya organisasi (X3) sama dengan nol, maka kinerja mengajar guru adalah positif

b. Nilai koefisien regresi untuk variabel kompetensi guru (X1) yaitu 0,313. Hal ini berarti bahwa motivasi berpengaruh positif terhadap kinerja mengajar guru

c. Nilai koefisien regresi untuk variabel motivasi berprestasi (X2) yaitu sebesar 0,054. Hal ini berarti motivasi guru berpengaruh sangat rendah terhadap kinerja mengajar guru

d. Nilai koefisien regresi untuk variabel budaya organisasi (X3) yaitu sebesar 0,094. Hal ini berarti budaya organisasi berpengaruh positif terhadap kinerja mengajar guru.

e. Hasil analisis dapat diketahui bahwa variabel bebas atau independen yang paling berpengaruh adalah kompetensi guru dengan nilai koefisien sebesar 0,313, sedangkan variabel yang berpengaruh paling rendah yaitu motivasi berprestasi dengan nilai koefisien 0,054, dari persamaan tersebut dapat terlihat bahwa semua variabel bebas berpengaruh positif dan terhadap kinerja mengajar guru.

\subsubsection{Koefisien Determinasi}

Koefisien determinasi mengukur seberapa jauh kemampuan variabel independen menjelaskan variabel dependen. Berikut ini tabel koefisien determinasi yang dihasilkan dalam penelitian:

Tabel 4.6

Hasil Koefisien Determinasi Model Summary

\begin{tabular}{|c|c|c|c|c|}
\hline Model & $\mathrm{R}$ & R Square & $\begin{array}{c}\text { Adjusted R } \\
\text { Square }\end{array}$ & $\begin{array}{c}\text { Std. Error of the } \\
\text { Estimate }\end{array}$ \\
\hline 1 & $0,484^{\mathrm{a}}$ & 0,234 & 0,193 & 3,41071 \\
\hline
\end{tabular}

Sumber: Data diolah, 2018

Berdasarkan tabel 4.6 dapat diketahui bahwa besarnya $\mathrm{R}^{2}$ adalah 0,484 , hal ini berarti 48,2\% variasi dari kinerja mengajar guru dapat dijelaskan oleh variasi dari ketiga variabel independen yaitu kompetensi guru (X1), motivasi 
berprestasi (X2) dan budaya organisasi (X3) sedangkan sisanya $(100 \%-48,2 \%=$ $51,8 \%$ ) dijelaskan oleh sebab-sebab lain yang tidak dapat dijelaskan dalam persamaan regresi tersebut atau faktor-faktor lain yang tidak diteliti dalam penelitian ini.

\subsubsection{Uji Validitas}

Uji validitas digunakan untuk benar-benar mengukur apa yang di ukur dan mengetahui bahwa suatu kuesioner di anggap valid ataupun tidak. Adapun dasar pengambilan keputusannya yaitu bahwa jika $\mathrm{r}$ hitung $>\mathrm{r}$ tabel, maka pernyataan tersebut di anggap valid. Begitupun sebaliknya, jika $r$ hitung $<\mathrm{r}$ tabel (pada taraf signifikansi 5\%) maka pernyataan tersebut tidak valid sehingga tidak dapat digunakan untuk pengujian selanjutnya. Untuk menguji validitas, 59 kuesioner telah disebarkan kepada responden. Adapun hasil pengujian adalah sebagai berikut:

Tabel 4.7

Hasil Uji Validitas

\begin{tabular}{|c|c|c|c|c|}
\hline Variabel & Item Pernyataan & Korelasi & $\mathrm{r}$ tabel & Keterangan \\
\hline \multirow{8}{*}{$\begin{array}{c}\text { Kompetensi } \\
\text { Guru (X1) }\end{array}$} & Item 1 & 0,440 & 0,300 & Valid \\
\hline & Item 2 & 0,381 & 0,300 & Valid \\
\hline & Item 3 & 0,341 & 0,300 & Valid \\
\hline & Item 4 & 0,344 & 0,300 & Valid \\
\hline & Item 5 & 0,385 & 0,300 & Valid \\
\hline & Item 6 & 0,305 & 0,300 & Valid \\
\hline & Item 7 & 0,386 & 0,300 & Valid \\
\hline & Item 8 & 0,312 & 0,300 & Valid \\
\hline \multirow{8}{*}{$\begin{array}{c}\text { Motivasi } \\
\text { Berprestasi } \\
\text { (X2) }\end{array}$} & Item 1 & 0,424 & 0,300 & Valid \\
\hline & Item 2 & 0,564 & 0,300 & Valid \\
\hline & Item 3 & 0,426 & 0,300 & Valid \\
\hline & Item 4 & 0,517 & 0,300 & Valid \\
\hline & Item 5 & 0,368 & 0,300 & Valid \\
\hline & Item 6 & 0,533 & 0,300 & Valid \\
\hline & Item 7 & 0,415 & 0,300 & Valid \\
\hline & Item 8 & 0,356 & 0,300 & Valid \\
\hline \multirow{7}{*}{$\begin{array}{l}\text { Budaya } \\
\text { Organisasi } \\
\text { (X3) }\end{array}$} & Item 1 & 0,357 & 0,300 & Valid \\
\hline & Item 2 & 0,368 & 0,300 & Valid \\
\hline & Item 3 & 0,362 & 0,300 & Valid \\
\hline & Item 4 & 0,290 & 0,300 & Tidak Valid \\
\hline & Item 5 & 0,457 & 0,300 & Valid \\
\hline & Item 6 & 0,331 & 0,300 & Valid \\
\hline & Item 7 & 0,367 & 0,300 & Valid \\
\hline
\end{tabular}




\begin{tabular}{|c|c|c|c|c|}
\hline \multirow{4}{*}{ Kinerja } & Item 1 & 0,399 & 0,300 & Valid \\
\cline { 2 - 5 } Mengajar & Item 2 & 0,359 & 0,300 & Valid \\
\cline { 2 - 5 } Guru (Y) & Item 3 & 0,329 & 0,300 & Valid \\
\cline { 2 - 5 } & Item 4 & 0,383 & 0,300 & Valid \\
\cline { 2 - 5 } & Item 5 & 0,323 & 0,300 & Valid \\
\cline { 2 - 5 } & Item 6 & 0,237 & 0,300 & Tidak Valid \\
\cline { 2 - 5 } & Item 7 & 0,388 & 0,300 & Valid \\
\hline
\end{tabular}

Sumber: Data diolah, 2018

Berdasarkan tabel 4.7 di atas dapat diketahui bahwa keseluruhan item pernyataan memiliki korelasi yang lebih dari $\mathrm{r}$ tabel $=0,300$ (nilai $\mathrm{r}$ tabel didapatkan dari $\mathrm{n}=30$ ) dinyatakan valid dan terdapat dua butir yang tidak valid, yaitu butir pada kinerja mengajar guru dan budaya organisasi.

\subsubsection{Uji Reliabilitas}

Uji reliabilitas digunakan untuk mengetahui sejauh mana alat ukur dapat dipercaya atau diandalkan. Dalam hal ini, hasil pengukuran kuesioner konsisten atau tetap bila dilakukan pengukuran berulang dan dapat digunakan lebih dari satu kali. Dengan dasar pengambilan keputusan yaitu jika nilai koefisien alpha > 0,60 maka kuesioner dinyatakan reliabel. Adapun hasil dari uji reliabel adalah sebagai berikut:

Tabel 4.8

Hasil Uji Reliabilitas

\begin{tabular}{|c|c|c|}
\hline Variabel & Alpha & Keterangan \\
\hline Kompetensi Guru(X1) & 0,734 & Reliabel \\
\hline Motivasi Berprestasi (X2) & 0,987 & Reliabel \\
\hline Budaya Organisasi (X3) & 0,375 & Tidak Reliabel \\
\hline Kinerja Mengajar Guru (Y) & 0,849 & Reliabel \\
\hline
\end{tabular}

Sumber: Data diolah, 2018

Berdasarkan tabel 4.8 dapat diketahui bahwa keseluruhan variabel lebih besar dari 0,60 sehingga dikatakan ada reliable pada tiga variabel yaitu Kompetensi guru, motivasi berprestasi, dan kinerja mengajar guru. Sedangkan variabel budaya organisasi memberikan informasi tidak reliable. Artinya kuesioner tersebut ada tidak dapat digunakan lebih dari satu kali dan tidak dapat diandalkan untuk digunakan pada tempat lain. 


\subsection{Pembahasan Hasil Penelitian}

Pembahasan hasil penelitian diawali dari uji persyaratan analitis, yaitu dimulai dengan uji linieritas, homoksedatisitas, dan validitas dan reliabilitas.

\section{Linieritas}

Hasil output SPSS menunjukkan bahwa grafil linieritas berada pada garis lurus yang ditunjukkan pada gambar berikut ini:

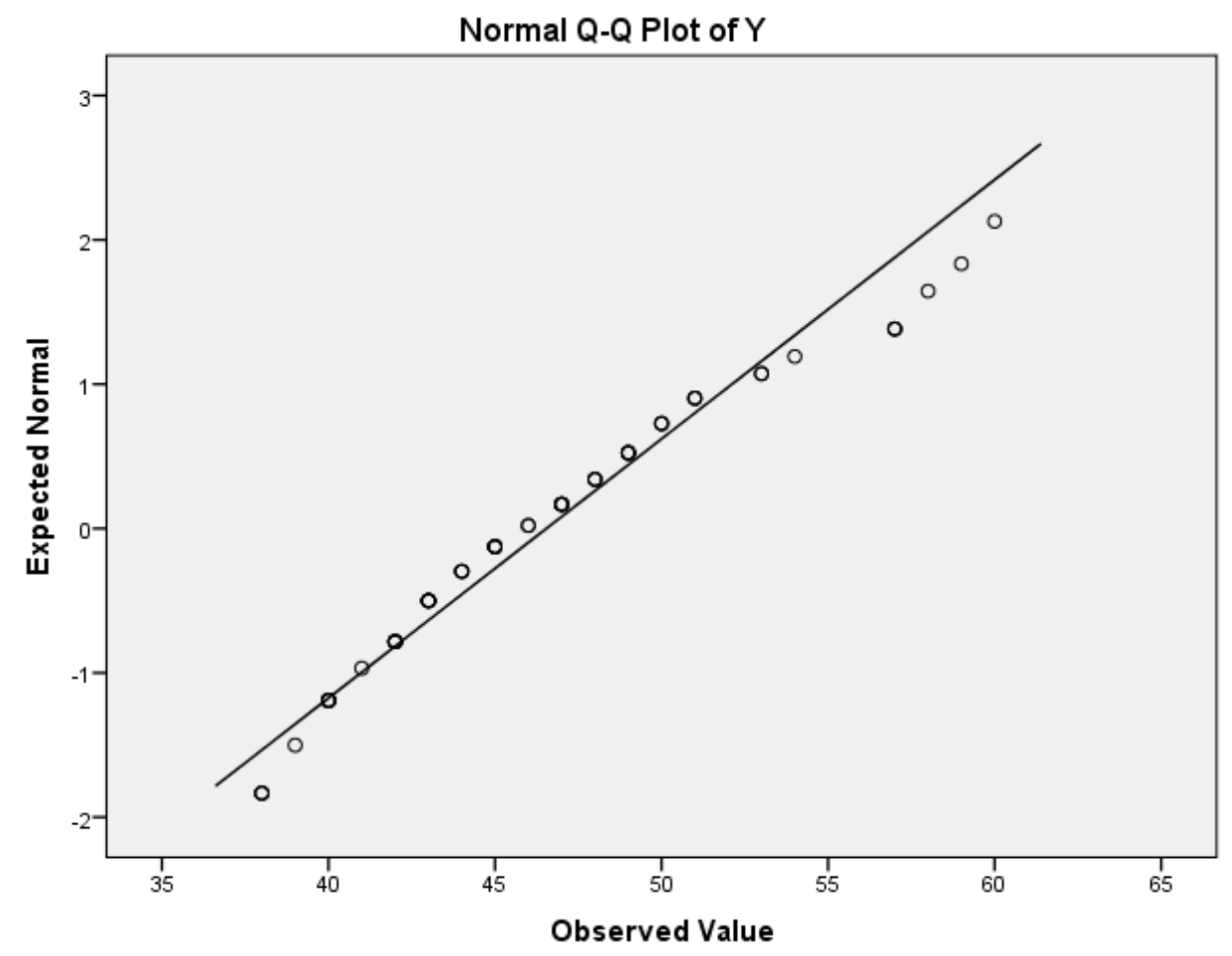

Hal ini menunukkan bahwa data ini memenuhi syarat linieritas untuk dilakukan analisis regresi.

Analisis regresi berganda untuk mengetahui pengaruh kompetensi guru, motivasi berprestasi, dan budaya organisasi terhadap kinerja mengajar guru dengan SPSS diperoleh persamaan Y = 20,405 + 0,313 (Kompetensi Guru) + 0,054 (Motivasi Berprestasi) + 0,094 (Budaya Organisasi) + e, menyatakan bahwa jika ada kompetensi guru (X1), motivasi berprestasi (X2), dan budaya organisasi (X3) dianggap konstan, maka kinerja mengajar guru akan sama dengan 20,405. Dan 0,313 menyatakan bahwa setiap penambahan satu poin kompetensi guru (X1) maka akan menambah kinerja mengajar guru (Y) sebesar 0,313, 0,054 menyatakan bahwa setiap penambahan satu poin motivasi berprestasi (X2) maka kinerja mengajar guru (Y) akan meningkat sebesar 0,054. Sedangkan 0,094 menyatakan bahwa setiap penambahan satu poin budaya organisasi (X3) maka kinerja mengajar guru (Y) akan meningkat sebesar 0,094.

Analisis satu-satu pada variabel dikemukakan berikut ini: 
1. Kompetensi Guru; kompetensi yang diukur adalah kompetensi professional menunjukkan nilai yang signifikan yaitu sebesar 0,313. Pada prinsipnya, besarnya koefisien pada pada variabel ini menunjukkan 31,3 persen dapat ditunjukkan oleh guru dalam kaitannya dengan kemitraan MI dengan PGMI. Hal ini memberikan gambaran yang sangat baik, bahwa kemitraan lembaga pendidikan dasar dengan lembaga pendidikan tinggi dapat menciptakan kompetensi guru terutama pada kompetensi professional.

Kompetensi professional terlihat pada kemampuan menguasai mata pelajaran, kemampuan memberikan penguatan-penguatan dan pengayaan dalam setiap mata pelajaran di kelas mereka. Aspek lain yang termuat dalam kompetensi professional ini adalah kemampuan guru belajar sepanjang hayat. Artinya, guru MI mitra PGMI dapat mengikuti perkembangan dengan cara belajar melalui bebabagi sumber belajar yang ada sekarang ini. Misalnya dapat membuat blog pribadi, sehingga dapat meng upload tulisan-tulisannya tentang materi pelajaran yang diampunya. Termasuk pula dalam hal ini kemampuan guru untuk melalukan pembelajaran daring di dalam kelas, maupun di luar kelas.

2. Motivasi berprestasi; motivasi berprestasi adalah kegiatan-kegiatan yang dilakukan oleh guru MI mitra PGMI yang dapat mendukung dirinya untuk berprestasi. Mendapatkan penghargaan dari atasan dan mendapatkan promosi jabatan. Motivasi berprestasi terkait dengan penelitian tindakan kelas, kegiatan musyawarah guru mata pelajaran, mengikuti kegiatan seminar, diskusi rutin bersama dengan temanj sejawat dengan menghadirkan pengawas atau pejabat yang lebih tinggi.

Motivasi berprestasi dari guru MI masih sangat rendah, yakni hanya memberikan 5,4 persen yang mendukung kinerjanya. Hal ini menunjukkan bahwa motivasi untuk berprestasi masih sangat rendah. Oleh karena itu perlu sebuah langkah yang positif dapat membangun semangat berprestasi dari para guru MI yang menjadi mitra PGMI UMI Makassar.

3. Budaya Organisasi; budaya organisasi adalah hubungan antara individu dengan seluruh unsur-unsur yang ada dalam sebuah organisasi madrasah. Unsur-unsur tersebut adalah Kepala Madrasah, guru, pegawai, peserta didik, petugas lapangan, petugas kebersihan, satpam dan orang tua yang diwkili oleh komite Madrasah. Ciri-ciri budaya organisasi adalah saling sapa jika bertemu, penggunaan bahasa yang sopan, mematuhi tata tertib Madrasah, mengembangkan kerjasama diantara para guru. Budaya organisasi ini memberikan gambaran harmonisasi dalam lingkungan Madrasah. Artinya, hubungan yang harmonis dapat menciptakan motivasi dan budaya kerja yang baik. Namun ternyata memberikan kontriusi yang sangat rencah yaitu hanya 9,4 persendari seluruh komponen yang diteliti. Ini memberikan gambaran bahwa perlu sebuah inovasi yang dapat membangun budaya organisasi di Madrasah. Variabel ini penting untuk mengukur tingkat partisipasi seluruh pihak dalam meningkatkan kualitas Madrasah, dan kualitas pembelajaran khususnya. Apabila budaya organisasi 
tidak baik, maka dapat dicurigai bahwa terjadi ketidakharmonisan hubungan antara berbagai unsur yang ada dalam Madrasah.

Berdasarkan kajian ini, maka peran stakeholder dapat mengambil bagian penting untuk membangun budaya organisasi di Madrasah. Peran tersebut untuk menciptakan suasana yang harmonis, penuh kekeluargaan dan penuh keakraban. Melaksanakan tugas sesuai tupoksi yang ada, memberikan penghargaan dan memberikan hukuman sesuai standar yang ditetapkan oleh Madrasah.

4. Kinerja Guru; kinerja guru yang diukur adalah konstribusi seluruh variabel yang diukur dalam penelitian ini yang mencerminkan kinerja guru tersebut. Kinerja guru meliputi perencanaan, pelaksanaan dan penilaian hasil belajar yang dapat dipengaruhi oleh kompetensi profesional, motivasi berprestasi, dan budaya organisasi.

Kompetensi professional, motivasi berprestasi dan budaya organisasi dapat menumbuhkan semangat untuk menyusun pembelajaran yang lebih baik, dapat menjadi pemicu dalam melaksanakan pembelajaran yang lebih baik, dan menjadi bagian penting dari budaya organisasi. Rendahnya kontribusi variabel yang diteliti dalam mengukur kinerja guru memberikan gambaran bahwa masih perlu peningkatan kerjasama antara program studi PGMI dengan mitranya. Kemitraan harus dibangun lebih baik untuk menciptakan suasana yang lebih baik, meningkatkan motivasi untuk berprestasi, meningkatkan kompetensi professional dan membangun budaya organisasi yang lebih baik.

\section{A. Simpulan}

\section{PENUTUP}

Berdasarkan hasil penelitian dan pembahasan yang dikemukakan pada BAB IV, maka dikemukakan simpulan sebagai berikut:

1. Kompetensi professional guru berpengaruh secara signfifikan terhadap kinerja mengajar guru. Besarnya konstribusi yang ditemukan adalah 31,3 persen.

2. Motivasi berprestasi guru berpengaruh secara signifikan terhadap kinerja mengajar guru (tetapi pada kategori rendah), yaitu sebesar 5,4 persen.

3. Budaya organisasi berpengaruh secara signifikan terhadap kinerja mengajar guru meskipun pada taraf yang rendah yaitu 9,4 persen.

4. Secara umum, kinerja guru dipengaruhi oleh kompetensi, motivasi dan budaya organisasi.

\section{B. Saran}

1. Kompetensi profesonal guru MI mitra PGMI FAI-UMI Makassar harus menjadi perhatian dalam kelanjutan kerjasama dan kemitraan. Hal ini sangat penting agar kinerja program studi PGMI dapat mengukur dirinya tingkat penguasaan mahasiswa terhadap semua unsur penunjang dalam membentuk kompetensi professional.

2. Motivasi berprestasi guru MI mitra PGMI harus dibangun dalam bentuk kegiatan-kegiatan agar motivasi berprestasi dapat menjadi bagian dari diri mereka dan dapat menunjukkan kompetensi mereka. Kegiatan yang dapat 
dilakukan lomba kreativitas pembelajaran, lomba penggunaan media pembelajaran, dan lomba peningkatan kompetensi guru dan peserta didik.

3. Menumbuhkan budaya organisasi dapat dilakukan dengan berbagai kegiatan pelatihan dan pendampingan. Prodi dapat memilih kegiatan-kegiatan tertentu untuk membantuk mitra dalam membentuk budaya organisasi menjadi lebih baik. Kegiatan tersebut antara pelatihan manajemen berbasis madrasah, pengambilan keputuasn berbasis kelompok dan komunitas.

5. Secara umum, kinerja guru dapat dibangun dengan memperbaiki tiga unsur utama yaitu kompetensi, motivasi dan budaya organisasi.

\section{Tindak Lanjut}

Tindak lanjut yang dapat dilakukan adalah menghimbau ketua rogram studi PGMI untuk melaksanakan berbagai kegiatan yang dapat membangun kembali semangat kemitraan antara MI dengan PGMI. Semangat kemitraan dapat dibangun dengan cara melakukan berbagai kegiatan antara guru dengan dosen, praktik pembelajaran, pelatihan penyusunan karya ilmiah, penyusunan bahan ajar yang berkualitas, dan segala hal yang tujuannya untuk meningkatkan kualitas Madrasah Ibtidaiyah

\section{DAFTAR PUSTAKA}

Arikunto. Suharsimi. Prosedur Penelitian Penelitian Suatu Pendekatan Praktik. Jakarta: Renika Cipta, 2006.

Djaali. Psikologi Pendidikan. Jakarta: Bumi Aksara, 2008. http://www.artikelsiana.com/2015/10/pengertian-budaya-organisasi-fungsi. html di akses tgl 18 Oktober 2017.

http://www.pelajaran.co.id/2017/28/pengertian-budaya-organisasi-fungsi-ciri-tipecontoh dan teori-budaya-organisasi.html di akses tgl 18 Oktober 2017.

Gunawan Heri. Kurikulum dan Pembelajaran Pendidikan Agama Islam. Bandung: Alfabeta, 2012.

Hasibuan S.P Malayu. Manajemen Sumber Daya Manusia. Jakarta: Bumi Aksara, 2008.

Riani, Asri Laksmi. Budaya Organisasi, Yogyakarta: Graha Ilmu, 2011

Rusman. Belajar dan Pembelajaran Berbasis Komputer. Bandung: Alfabeta, 2012. ,Model-model Pembelajaran. Jakarta: Rajawali Pers, 2011.

Sudijono Anas. Pengantar Statistik Pendidikan. Jakarta: Raja Grafindo. 2000.

Sanjaya Wina. Penelitian Pendidikan. Jakarta: Kencana, 2013.

Sugiono. Metode Penelitian Pendekatan Kuantitatif, Kualitatif, dan R \& D. Bandung: Alfabeta, 2012.

Tim Reality. Kamus Terbaru Bahasa Indonesia. Surabaya: Reality Publisher, 2008. 